\title{
ANALYSIS OF THE REALITIES, EVOLUTION AND PROSPECTS OF URBAN GREENING FROM AN INTERNATIONAL POINT OF VIEW
}

\author{
Fernando Barriuso ${ }^{1}$ and Beatriz Urbano ${ }^{2 *}$ \\ ${ }^{1 / 2)}$ University of Valladolid, Palencia, Spain.
}

\author{
Please cite this article as: \\ Barriuso, F. and Urbano, B., 2020. Analysis of the \\ Realities, Evolution and Prospects of Urban Greening \\ from an International Point of View. Amfiteatru \\ Economic, 22(53), pp. 137-150.
}

\section{Article History}

Received: 2 August 2019

Revised: 10 November 2019

Accepted: 7 December 2019

DOI 10.24818/EA/2019/53/137

\begin{abstract}
There is an increasing concern about the imbalance between urbanisation and environmental conservation, with over half of the world's population living in urban environments. Therefore, urban greening aims to incorporate nature into the city, recovering native flora in a sustainable way. Urban greening is a multi-functional environmental benefit system that incorporates vegetation in urban cores. Urban greening has become one of the most innovative and rapidly developing fields in ecology, green procurement and the built environment. The aim of this study was to provide an insight into the realities, evolution and prospects of urban greening from an international point of view. A sample of 1,727 worldwide urban greening projects was analysed, a Pearson's chi-square test was used to study the evolution of urban greening, and a binary logistic regression was used to predict determinant factors of public urban greening. Results show urban greening is prevalent in well-developed urbanised cities, while is challenging in the world's fastest growing cities in low-income countries. Urban greening installation has significantly changed from intensive to extensive systems offering the most cost-effective solution, and currently to living walls due to the emergence of this technology. Urban greening has expanded significantly from university campuses and parks, for the general public's benefit, to streets for families' use. The urban greening projects were installed mainly in private, residential, commercial, educational and government buildings. The main motivations of urban greening projects were environmental or aesthetic purposes and research aims. The prospects show parks and for general public are determinant factors for public urban greening at global level. This study contributes to the literature by investigating the characteristics and evolution of urban greening systems and prospects of public urban greening from an international point of view.
\end{abstract}

Keywords: urban greening projects, sustainable cities, environmental commitment, time evolution, pearson's chi-square test, binary logistic regression.

JEL Classification: Q53, Q55, Q56

\footnotetext{
* Corresponding author, Beatriz Urbano - beatriz.urbano@uva.es
} 


\section{Introduction}

Since the mid-twentieth century, there has been an increasing concern about the imbalance between urbanisation and environmental conservation (Urbano-Lopez de Meneses, 2013). Therefore, urban greening aims at incorporating and promoting nature in the city cores, recovering native flora and fauna in an acceptable and sustainable way. Urban greening may be clearly identified as designed, built and maintained vegetation associated with buildings. By placing vegetation within the built space of the urban areas, raised urban heat islands can decrease (Alexandri and Jones, 2008, Park et al., 2020), greenhouse gas emissions can be reduced (Loh, 2008, Sun, Grimmond and Ni, 2016), environmental pollutants can be attenuated (Kim, Hong and Koo, 2012), urban storm-water runoff can be managed (Köhler and Poll, 2010, Lundholm et al., 2010, Mickovski et al., 2013, Qin et al., 2013, Yamanaka et al., 2020), noise can be reduced (Loh, 2008) and biodiversity can be enhanced (Castleton, et al., 2010). Therefore, urban greening has become one of the most innovative and rapidlydeveloping fields in ecology, green procurement and the built environment (Wong et al., 2010). Nevertheless, the higher costs when compared to more traditional options, the maintenance requirements and lack of environmental commitment might constrain urban greening generalisation. Therefore, and despite the undeniable environmental benefits of urban greening, there are still economic, technical and social barriers that need to be overcome for the wide and harmonious integration of greening in cities.

The aim of this study is to provide an insight into the implementation of urban greening and, in doing so, to analyse its evolution and to delineate prospects.

Therefore, the research questions of the study are:

- $\mathrm{RQ}_{1}$ : What are the characteristics of the urban greening systems at global level?

- $\mathrm{RQ}_{2}$ : How have the urban greening systems evolved at global level?

- $\mathrm{RQ}_{3}$ : What are the determinant factors for public urban greening at global level?

The paper is structured as follows. In the first part, the definition, benefits, progress and institutional support of urban greening systems are reviewed. In the second part, the research method is described in detail. In the third part, 1,727 urban greening projects are characterised, their evolution is analysed, and determinant factors of public urban greening are obtained. In the fourth part, conclusions and future research lines are presented.

\section{Review of the scientific literature}

Rapid urbanisation is a major concern, with over half of the world's population living in urban environments (Koprowska, Łaszkiewicza and Kronenberga, 2020; UNFPA, 2007). Buildings are responsible for $33 \%$ of greenhouse emission globally (Berardi, GhaffarianHoseini and GhaffarianHoseini, 2014), and urbanisation consumes large quantities of natural vegetation, replacing them with concrete buildings (Wong et al., 2010). In this sense, urban greening is a multi-functional and environmental beneficial system that incorporates vegetation in urban cores. Urban greening is often indicated as a valuable solution for resolving the lack of green space in urbanised areas, playing an important role in the environment of a city and the microclimate of buildings (Sun, Grimmond and $\mathrm{Ni}$, 2016). The benefits of urban greening are related to the reduction of building energy consumption, mitigation of the urban heat island effect, improvement of air pollution, water 
management, increase of sound insulation, and ecological preservation (Alexandri and Jones, 2008, Castleton, et al., 2010, Kim, Hong and Koo, 2012, Köhler and Poll, 2010, Loh, 2008, Lundholm et al., 2010, Mickovski et al., 2013, Park et al., 2020, Qin et al., 2013, Yamanaka et al., 2020). In this sense, urban greening contributes to more sustainable buildings and cities (Berardi, GhaffarianHoseini and GhaffarianHoseini, 2014).

Given the growing concern about climate change, there has been increasing interest in using urban greening as part of a sustainable strategy for the urban environment (Loh, 2008, Yin et al., 2019). Urban greening is often identified as a valuable strategy for making cities more sustainable, and American organic architects have proposed urban greening as a method to integrate buildings and nature (Berardi, GhaffarianHoseini and GhaffarianHoseini, 2014). The outer surfaces of buildings offer a great amount of space for vegetation with environmental benefits (Wong et al., 2010).

Urban greening is vegetation that can fully or partially cover a built surface. It is a layered system composed by an upper vegetation part, formed by the growing medium and the vegetation itself, and a building protection part composed of a waterproofing membrane, a root barrier layer and a drainage layer (Castleton et al., 2010).

Urban greening systems can be classified into intensive or extensive greening, according to their intensity. Extensive greening has low-height vegetation, typically sedum or lawn, with a thin substrate layer and a lightweight structure. Intensive greening has a deep substrate layer where deeper rooting plants, such as shrubs and even trees, can survive with a heavy structure (Yin et al., 2019). Moreover, urban greening systems can be classified, according to the built surface covered, into green roofs, in which a horizontal or sloped surface is greened, and living walls, with a vertical façade greened with around $100 \%$ of slope. Living walls are also called green walls, green façades, bio walls or vertical vegetation. The term refers to vegetation that grows in the front of the building's façade or to vegetation that is grown on a separate structural system of the wall (Loh, 2008). Finally, urban greening systems can be classified into existing buildings greening or greening systems for new constructions (Hong, Guo and Tang, 2019). In this sense, Loh (2008) noted that integrating urban greening during the initial design stages can minimise the cost and maximise benefits. Nevertheless, to make an impact, wide-scale installation of urban greening will therefore have to take place as retrofitting of existing buildings (Steadman, Rickaby and Brown, 2000). In the UK, Brown et al. (2000) showed that over $50 \%$ of existing nondomestic buildings were built before 1965, when insulation was not required in building design. In this line, Niachou et al. (2001) demonstrated the potential energy savings urban greening could bring for heating: up to $45 \%$ for non-insulated buildings and $13 \%$ in moderately insulated buildings. Older buildings are generally less well insulated (Castleton et al., 2010) and can benefit from urban greening's insulating properties, which could offer substantial energy savings throughout the year (Brown et al., 2000).

Literature shows that Germany has experienced the largest uptake of green roof technology, where the industry was reported to be worth $\$ 77$ million in 2008 (CNN Technology, 2008). In this sense, Buildingradar (2019) pointed out that green roofs comprise 86 million $\mathrm{m}^{2}$ in Germany. By the same token, literature shows that a good research base on the environmental performance of vertical greenery systems has been developed in Germany over the last twenty years, where regulations and guidelines have been published (Wong et al., 2010). In the case of London, Livingroofs (2019) reported that the total area of green 
roofs in the Greater London was 1.5 million $\mathrm{m}^{2}$ in 2017. In contrast, Williams, Rayner and Raynor (2010) showed a poor uptake of green roof technology in Australia.

Many policies worldwide are encouraging more sustainable cities through urban greening (Popescu et al., 2012). Examples are reported in Europe, where Germany is supporting the construction of 13.5 million $\mathrm{m}^{2}$ of green roofs every year. For instance, in Esslingen, 50\% of the cost of green roofs is paid back, while in Darmstadt, users can receive up to $5000 €$ for installing a green roof. In the cities of Bonn, Cologne and Mannheim, the allocated stormwater fees are considerably reduced once new green roofs are built. Similar policies have been applied in other countries, such as Switzerland and Austria. In Basel, 20\% of the cost of a green roof is paid back (Brenneisen, 2004). The Government Office of London encouraged urban greening by way of a $6.0 € / \mathrm{m}$ greened grant (Castleton et al., 2010). In Canada, the city of Toronto has specific policies promoting green roofs in buildings with a coverage ratio of $50-70 \%$ of the entire building, while in Quebec, an economic incentive is provided per square meter of green roofs (Carter and Fowler, 2008). In the U.S., some states have established specific policies, especially in highly urbanised areas. For instance, in Oregon, $70 \%$ of the roofs in Portland were planned to be covered with green roof (Carter and Fowler, 2008). In Japan, the law in Tokyo requires the installation of green roofs in private buildings with built areas larger than $1000 \mathrm{~m}^{2}$ and in public buildings with built areas larger than $250 \mathrm{~m}^{2}$, while integrated green roofs must encompass not less than $20 \%$ of the whole rooftop area (Brenneisen, 2004).

Moreover, many authorities are also involved in undertaken the urban greening in cities. For instance, the Ethelred Estate in London has recently added extensive green roof systems to over $4000 \mathrm{~m}^{2}$ of flat rooftops to provide a better environment, added value and sense of well-being for the community, making Ethelred the largest green roof retrofit case in the UK. The government of Singapore is championing more innovative ways to integrate greenery into buildings, and vertical greening systems in Singapore seems encouraging (Wong et al., 2010) in realising Singapore's vision of a 'City in the Garden'.

Additionally, community gardens are construed as an urban greening strategy and are remedies to neighbourhood blight and general urban environmental degradation (Comstock et al., 2010, Kurtz, 2001). By promoting outdoor physical activity, gardens are said to support public health efforts to improve community well-being (Comassetto et al., 2013, Yee Tse, 2010). Additionally, garden projects are widely used as a source of employment and training for incarcerated adults and youth (Pudup, 2008). More generally, garden projects are a place to connect city kids with nature (Barfod et al., 2016) and thereby yield many individual and social benefits (Beilin and Hunter, 2011, Egerer et al., 2019). Milligan, Gatrell and Bingley (2004) found the sense of achievement, satisfaction and aesthetic pleasure that older people can gain from gardening activity which combats social isolation, contributes to the development to their social networks and creates 'therapeutic lanscapes' (Pudup, 2008). Another impetus to the community garden movement was alarm over food security, particularly in poor urban neighbourhoods experiencing lack of access to fresh foods (FAO, 2012).

\section{Research methodology}

In order to provide an insight into the implementation, realities and prospects of urban greening a combination of research methods was used according to the aims of the study. A 
sample of 1,727 worldwide urban greening projects from the Greenroofs.com Projects database was analysed. Greenroofs.com Projects Database collects global projects in the international arena and products and services. Architects, landscape architects, governments, contractors, building owners and a multitude of other professionals can see who designed these projects and which products are greening the buildings.

In the first step of the research, urban greening projects were analysed in order to characterise the implementation and realities of urban greening. The Greenroofs.com Projects Database was used to gather the year of greening, extension, intensity, slope and building owner. Google Maps was used to identify the location of the projects and the type of building. Then, projects were classified using the Koppen-Geiger climate group classification. Finally, the population of the area of the project was obtained using the UNFPA (2007) database. These data were collected from 1 February to 31 May, 2018.

In the second step of the research, the urban greening projects were contacted to obtain the data of the beneficiaries, aims and purpose of urban greening projects (table no. 1).

Table no. 1: Urban greening variables including the type of variable and data gather

\begin{tabular}{|l|l|l|}
\hline \multicolumn{1}{|c|}{ Variable } & \multicolumn{1}{c|}{ Type variable } & \multicolumn{1}{c|}{ Data gather } \\
\hline Year of greening & Qualitative & Greenroofs.com \\
\hline Extension & Quantitative & Greenroofs.com \\
\hline Population & Quantitative & UNFPA (2007) \\
\hline Slope & Quantitative & Greenroofs.com \\
\hline Location & Qualitative & $\begin{array}{l}\text { Greenroofs.com } \\
\text { Google maps }\end{array}$ \\
\hline Climate group & Qualitative & Koppen-Geiger classification \\
\hline Continent & Qualitative & Google maps \\
\hline Ownership & Dichotomous & Greenroofs.com \\
\hline Maintenance & Dichotomous & Greenroofs.com \\
\hline Intensity & Qualitative & Greenroofs.com \\
\hline Building type & Qualitative & $\begin{array}{l}\text { Greenroofs.com description } \\
\text { Google maps }\end{array}$ \\
\hline Greening beneficiaries & Qualitative & Survey \\
\hline Greening aims & Qualitative & Survey \\
\hline Greening purpose & Qualitative & Survey \\
\hline
\end{tabular}

In the third step of the research, data were analysed. First, a frequency analysis was conducted to characterise the 1,727 urban greening projects. Then, relationship between year of construction and the rest of the variables was calculated using a Pearson's chi-square $\left(\chi^{2} .{ }_{95}\right)$ test in order to analyse the evolution of the urban greening projects. To accept or reject the null hypothesis $\left(H_{0}\right.$, which implies no relationship between the variables), the value of the $\chi^{2}$ statistic and the respective $\mathrm{P}$ values were considered, and dependence was determined in light of the frequencies expected and obtained and the corresponding corrected typified residues (c.t.r.). For variables with $\mathrm{P}<0.05$, the null hypothesis was rejected.

Then, a binary logistic regression was used to predict the odds of being public urban greening based on the values of the predictors. A correlation matrix was constructed to test possible multicollinearity among variables. Pearson's correlation coefficient was used, and high correlations were considered if their values were greater than 0.800 (Verbeke, 2015). 
Regression coefficients were estimated using maximum likelihood estimation and were presented with Wald $\chi^{2}$-statistics and as odds ratios, by using the Wald forward stepwise method. The model revealed the most important predictors of public urban greening. SPSS v.24.0 was used for the analysis.

\section{Results and discussion}

Urban greening, despite the growing increase in the period 2000-09, has been sluggish or stagnating over the last decade. The decrease of urban greening since 2010 might be attributable to the economic crisis, due to the higher initial and maintenance additional costs of urban greening compared to more traditional options. Carter and Keeler (2008) demonstrated that in terms of whole-life cost analysis, a green roof is 10-14\% more expensive than a conventional roof over a 60-year lifetime. Current data on the cost of urban greening generally only indicates the capital outlay in the installation and the operational cost of their maintenance, without indicating the potential for lowering of building energy costs due to their insulative properties (Zhang et al., 2019). Moreover, the capacity of the greening systems to limit the fluctuation of building surface temperatures is valuable in prolonging the lifespan of building surfaces and slowing down cost savings in maintenance and replacement of building parts (Wong et al., 2010). Additionally, the positive social and environmental benefits of urban greening should not be overlooked and might provide an additional incentive to managers' and citizens' decisions. The future adoption of urban greening in many countries will depend of economies of scale (Carter and Keeler, 2008, Hiu et al., 2010). The ability of urban greening to offer a more pleasant, healthier and more productive workplace, together with lower building energy bills and cost savings in maintenance and replacement of building parts, are incentives that should have particular appeal to both building owners and developers, without forgetting the many positive benefits of urban greening that can help improve our urban environment, as well as lower greenhouse gas emissions.

The average extension of the urban greening projects ranged from 2.00 to $115,000 \mathrm{~m}^{2}$, with an average of $2095.58 \pm 7337.29$. Most of the urban greening projects of the sample were owned privately $(69.7 \%)$, while the majority of community gardens are public owned (Abass, Appiah and Afriyie, 2019, Guitart, Pickering and Byrne, 2012). Nevertheless, no significant evolution in time was found in the urban greening ownership.

The average slope of the urban greening projects in the sample was $10.85 \pm 25.95$, of which the majority were extensive greening systems $(65.1 \%)$ compared to intensive greening $(22.8 \%)$. This might be because extensive greening offers a more cost-effective solution than intensive, is relatively low-maintenance (Akther et al., 2018) and is preferred for existing buildings because the structural capacity of the roof will often not have to be increased (Dunnet and Kingsbury, 2004). The result is in consonance with Buildingradar (2019) that indicated 85\% of green roofs in Germany are extensive. Moreover, in the sample, only 249 out of 1,727 projects declared maintenance, of which $76.3 \%$ were American projects, $16.1 \%$ European, $6.0 \%$ Asian and $1.6 \%$ from Oceania. In contrast, in the sample, only $6.04 \%$ of projects involved external living walls and $0.8 \%$ interior living walls. The low number of vertical greening projects found might be explained by the fact that living walls technology is still emerging, and there is limited technical data available at present (Zhang et al., 2019). Living walls have yet to be fully explored and exploited (Wong et al., 2010). 
Urban greening in the sample was concentrated in two primary world climatic groups, Group C (67.17\%) and Group D (25.66\%), while only a few projects were found in Group A $(3.82 \%)$ and Group B $(3.36 \%)$ regions. The uneven distribution of urban greening is not surprising, because the implementation of urban greening is prevalent in well-developed urbanised cities, many of which are situated in Group C and Group D climate regions. Additionally, the cost might constrain urban greening implementation in developing areas. Several developed countries have promoted urban greening and formulated guidelines and regulations for its wide implementation (Akther et al., 2018). Along these lines, Guitart, Pickering and Byrne (2012) pointed out that most of the literature of urban greening is based in cities in the U.S. Schweitzer and Erell (2014) highlighted that it is very challenging to implement urban greening in extremely hot and dry regions in developing areas.

Ninety percent of the urban greening samples were located in cities with less than 4.8 million inhabitants (average 1,474,597 $\pm 2,764,572.42$ ) (table no. 2), and $94.7 \%$ of them were located in Europe or the Americas (Akther et al., 2018), while most of the world's fastest-growing cities are found in low-income countries in Asia and Africa with young populations. Over the next 10 years, the current number of urban dwellers in sub-Saharan Africa is expected to grow by almost 45 percent, from 320 million to 460 million. Kinshasa, capital of the Democratic Republic of the Congo, one of the world's poorest countries, is now the world's fastest growing future megacity. By 2025, the urban population of the least-developed countries in Asia will have grown from 90 million to a projected 150 million, and Dhaka, Bangladesh, is expected to become the world's fifth largest city, with 21 million inhabitants (FAO, 2019).

Table no. 2: Profile of the urban greening projects of the sample $(1,727)$.

Relative frequency expressed in percentage

\begin{tabular}{|l|l|l|l|l|l|}
\hline \multicolumn{1}{|c|}{ Variable } & \multicolumn{1}{|c|}{ Cases } & \multicolumn{1}{c|}{ V } & \multicolumn{1}{c|}{ Variable } & \multicolumn{1}{c|}{ Cases } & \multicolumn{1}{c|}{ \% } \\
\hline Year & $2000-2009$ & 62.90 & Location & Street & 50.23 \\
\hline & $2010-2018$ & 32.57 & & Avenue & 24.24 \\
\hline & $1914-1999$ & 4.53 & & Park & 14.99 \\
\hline Intensity & Extensive & 65.08 & & Boulevard & 7.09 \\
\hline & Intensive & 22.83 & & Campus & 3.45 \\
\hline & Living walls & 6.04 & Continent & America & 82.32 \\
\hline & Semi-intensive & 5.22 & & Europa & 12.42 \\
\hline & Interior wall & 0.83 & & Asia & 4.11 \\
\hline Koppen- & Climate group C & 67.17 & & Oceania & 0.98 \\
\hline Geiger group & Climate group D & 25.65 & & Africa & 0.17 \\
\hline & Climate group A & 3.82 & Ownership & Private & 69.70 \\
\hline & Climate group B & 3.36 & & Public & 30.30 \\
\hline
\end{tabular}

The main beneficiaries of urban greening were building users, families and education communities (94.49\%). Nevertheless, in the case of the groups operating community gardens, Guitart, Pickering and Byrne (2012) indicated that non-profit organisations, including cultural and neighbourhood groups (82\%), schools, hospitals, jails, women's or senior centres, housing complexes and residents are the main beneficiaries of this urban greening. 
It was found that four main types of buildings incorporate urban greening: residential (22.8\%), commercial $(21.81 \%)$, educational $(16.71 \%)$ and governmental $(11.08 \%)$ (table no. 3). This result is in consonance with Steadman, Rickaby and Brown (2000), who illustrated the great opportunity offered by greening for commercial and institutional buildings, which are normally repaired and refurbished every 15-20 years. In a report compiled for Manchester City Council, Deloitte and Grant (2009) pointed out that green roofs are technically feasible for most commercial or institutional buildings in the city. In this sense, Wilkinson and Reed (2009) analysed the potential of retrofitting greening to existing buildings in the Central Business District of Melbourne, Australia. The study addresses the large-scale potential of retrofitting, not just individual cases. It was concluded that approximately $15 \%$ of the building stock was suitable for retrofit. Castleton et al. (2010) highlight that the load capacity of the existing roof structure is the predominant constraint when considering a retrofit green roof, while the overshadowing of the roof area and unfavourable orientation of the buildings in the city (Getter, Rowe and Cregg, 2009) should also determine the urban greening installation. In this sense, UK medium-rise office buildings with concrete roofs could probably be retrofitted with a green roof with no additional structural modifications. Buildings over thirty years old often have more reserve capacity than newer buildings due to the improved structural efficiency of modern analysis, design and construction methods.

Table no. 3: Building use, beneficiaries and aims of urban greening projects $(1,727)$. Relative frequency expressed in percentage

\begin{tabular}{|l|l|l|l|l|l|}
\hline Variable & \multicolumn{1}{|c|}{ Cases } & \multicolumn{1}{c|}{ V } & \multicolumn{1}{c|}{ Variable } & \multicolumn{1}{c|}{ Cases } & \multicolumn{1}{c|}{$\%$} \\
\hline Building use & Residential & 22.80 & Beneficiaries & Building users & 71.42 \\
\hline & Commercial & 21.81 & & University users & 12.58 \\
\hline & Educational & 16.71 & & Family & 10.49 \\
\hline & Governmental & 11.08 & & General citizens & 3.65 \\
\hline & Enterprise & 6.55 & & Researchers & 1.86 \\
\hline & Multipurpose & 5.34 & Aims & Environmental & 33.30 \\
\hline & Hospital & 4.47 & & Aesthetic & 29.05 \\
\hline & Park & 2.26 & & Research & 23.17 \\
\hline & Aviation & 1.80 & & Leisure & 5.70 \\
\hline & Museum & 1.45 & & Food supply & 3.44 \\
\hline & Non-profit org & 1.16 & & Educational & 2.44 \\
\hline & Parking & 0.93 & & Therapy & 1.63 \\
\hline & Library & 0.93 & & Revalorization & 1.27 \\
\hline & Religious & 0.70 & & & \\
\hline & Industry & 0.56 & & & \\
\hline & Others & 1.45 & & & \\
\hline
\end{tabular}

Prospects show that urban greening of existing structures additionally requires a structural survey in order to determine a building's load-bearing capacity before designing the retrofit for a greening. The weight of the greening system must first be considered when determining the potential to retrofit. Therefore, the design should consider the load capacity of the existing roof structure, the overshadowing of the existing roof, the orientation as the different possible substrate depths, type of plants and plant density according to local climates and water availability, among other issues. The future adoption of urban greening in many countries will depend on expertise. 
The main motivation found for urban greening was environmental or aesthetic purposes $(62.3 \%)$, with nearly a quarter of the urban greening projects having research aims $(23.2 \%)$. In the case of community gardens, Guitart, Pickering and Byrne (2012) found that the main aims are producing fresh foods, social development or cohesion, improving health among members and making or saving money by selling the produce or eating from the garden, while education, enhancement of cultural practices, access to land, nature and environmental sustainability were found as secondary motivations of the community gardeners (Egerer et al., 2019).

The contingency analysis revealed a significant evolution in the intensity of urban greening systems. Before 1999, the implementation of intensive urban greening systems was more likely $(\mathrm{P}=0.000$, c.t.r. $=6.3$ ), while from 2000 to 2009 , it was more highly probable that extensive greening systems would be installed $(P=0.000$, c.t.r. $=5.7)$. From 2010 , the installation of living walls is significantly highly probable $(P=0.000$, c.t.r. $=10.6)$. This result might be due to the development of living walls technology over the last decade. The effectiveness and environmental benefits of living walls have been demonstrated (Zhang et al., 2019), becoming a new green way of interest. Living walls are an emerging technology that offers a new way to green the built environment (table no. 4).

Table no. 4: Contingency of the urban greening evolution, relative frequency expressed in percentage and Pearson's chi-square test of significance expressed in the value of the $\chi^{2}$ statistic and the respective $P$ values

\begin{tabular}{|c|c|c|c|c|c|c|}
\hline Variable & Cases & 1914-99 & $2000-09$ & $2010-18$ & $\chi^{2}$ & $\mathbf{P}$ \\
\hline \multirow[t]{5}{*}{ Intensity } & Extensive & 50.5 & 70.1 & 57.6 & \multirow{5}{*}{164.03} & \multirow{5}{*}{0.000} \\
\hline & Intensive & 47.1 & 15.0 & 20.6 & & \\
\hline & Living walls & 0.0 & 0.4 & 15.2 & & \\
\hline & Semi-intensive & 2.0 & 12.5 & 6.0 & & \\
\hline & Interior wall & 0.0 & 2.0 & 0.4 & & \\
\hline \multirow[t]{5}{*}{ Continent } & Africa & 0.0 & 0.1 & 0.4 & \multirow{5}{*}{146.61} & \multirow{5}{*}{0.000} \\
\hline & America & 48.6 & 84.5 & 84.5 & & \\
\hline & Asia & 5.8 & 3.0 & 6.0 & & \\
\hline & Europa & 45.6 & 12.0 & 6.8 & & \\
\hline & Oceania & 0.0 & 0.4 & 2.3 & & \\
\hline \multirow[t]{5}{*}{ Location } & Avenue & 13.6 & 25.4 & 23.1 & \multirow{5}{*}{33.611} & \multirow{5}{*}{0.000} \\
\hline & Boulevard & 5.8 & 6.6 & 7.9 & & \\
\hline & Campus & 6.8 & 3.2 & 3.2 & & \\
\hline & Park & 16.5 & 17.5 & 9.4 & & \\
\hline & Street & 57.3 & 47.3 & 56.4 & & \\
\hline \multirow[t]{5}{*}{ Beneficiaries } & Building users & 66.0 & 74.3 & 67.0 & \multirow{5}{*}{78.894} & \multirow{5}{*}{0.000} \\
\hline & University users & 9.7 & 12.1 & 13.9 & & \\
\hline & Family & 7.8 & 9.3 & 13.2 & & \\
\hline & General citizens & 16.5 & 1.7 & 5.1 & & \\
\hline & Researchers & 0.0 & 2.5 & 0.9 & & \\
\hline
\end{tabular}

Evolution shows that urban greening installation is significantly decreasing in America and Europe, while holding steady in Asia and increasing in Oceania, in the last decade. The contingency analysis shows it is likely that urban greening was constructed before 1999 in Europe $(P=0.000$, c.t.r. $=10.6)$, from 2000 to 2009 in America $(P=0.000$, c.t.r. $=3.0)$ and 
from 2009 to 2018 in Asia or Oceania $(P=0.000$, c.t.r. $=2.7$ and 3.9 respectively). Results show there are challenges to urban greening in Asia and Africa, where the fastest growing cities are located.

The evolution shows it is significantly highly probable that before 1999, urban greening was located in university campus $(\mathrm{P}=0.000$, c.t.r. $=1.9)$; from 2000 to 2009 , it was likely constructed in parks $(\mathrm{P}=0.000$, c.t.r. $=4.0)$ and from 2010 in the streets $(\mathrm{P}=0.000$, c.t.r. $=3.2)$. The result makes sense: the prior urban greening was experimental and later parks were created due to their high visibility and general benefits to citizens, while current urban greening is constructed in the streets. Their location in streets is in consonance with the previous result of the increase in living walls, where greening decreases the urban heat island and reduces urban noise (Alexandri and Jones, 2008, Park et al., 2020).

The results show a significant evolution in the beneficiaries of urban greening. Before 1999 , it was highly probable that beneficiaries were the citizens in general, while from 2000 to 2009 , the most likely beneficiaries of urban greening were researchers and building users. Since 2010, it is mostly likely that families are beneficiaries of urban greening.

The contingency analysis shows it is likely that the public urban greening $(\mathrm{P}=0.000)$ were parks $($ c.t.r. $=8.9)$, governmental $($ c.t.r. $=6.9)$, parking (c.t.r. $=3.4)$, educational (c.t.r. $=$ 2.5 ), museum (c.t.r. $=2.4$ ) or library buildings (c.t.r. $=2.3$ ). Moreover, the result shows it is significantly highly probable $(\mathrm{P}=0.000)$ that the main beneficiaries of public urban greening were the citizens in general (c.t.r. $=10.6$ ) and university users (c.t.r. $=2.9$ ). This result is in consonance with the authorities' involvement to provide well-being for the general citizens (Abass, Appiah and Afriyie, 2019).

Multicollinearity was not a major issue at the public urban greening model. In table no. 5, the regression coefficients with their corresponding standard errors (SE), the value of the Wald statistic to evaluate the null hypothesis $(\beta \mathrm{i}=0)$, associated statistical significances and value of the OR $(\operatorname{Exp}(\beta))$ and goodness of fit statistics are presented.

Table no. 5: Public urban greening model using coefficient estimates and diagnostics from binary logistic regression and Wald forward stepwise method

\begin{tabular}{|l|c|c|c|c|c|c|}
\hline \multicolumn{1}{|c|}{ Positive determinant factor } & $\boldsymbol{\beta}$ & SE & Wald & gl & Sig. & $\operatorname{Exp}(\boldsymbol{\beta})$ \\
\hline Building use: Park & 2.511 & 1.133 & 4.910 & 1 & 0.027 & 12.313 \\
\hline Beneficiaries: General citizens & 2.890 & 0.540 & 28.593 & 1 & 0.000 & 17.994 \\
\hline Constant & -0.381 & 0.809 & 0.222 & 1 & 0.637 & 0.683 \\
\hline
\end{tabular}

Goodness-of-fit statistics of the model associated with public urban greening: -2Log likelihood statistic $=1765.16$; Hosmer-Lemeshow statistic $=0.616$; Overall success rate $=73.5 \%$ (Verbeke, 2015)

The regression model shows parks and for general citizens are positive determinant factors for public urban greening. This result might be explained due to the fact parks provide high visibility and general benefits to citizens (Abass, Appiah and Afriyie, 2019). Nevertheless, there is a challenge for authorities and institutions to consider alternative urban greening systems. The positive social and environmental benefits of alternative urban greening might provide an additional incentive to managers' decisions. The political commitment might determine prospects of public urban greening procurement (Heynen, Perkins and Roy, 2006). 


\section{Conclusions}

This research presents insight into the characteristics, evolution and prospects of urban greening systems from an international point of view. The results show that implementation of urban greening is prevalent in well-developed urbanised cities. Urban greening has been largely developed in America and Europe in the last decades, while there is a challenge for urban greening in the world's fastest-growing cities in low-income countries in Asia and Africa. The research shows that urban greening has significantly changed from intensive to extensive systems, offering the most cost-effective solution, and nowadays to living walls due to the emergence of this technology, which offers a new way to green the built environment. Urban greening has significantly moved from university campuses and parks, for general citizens' benefit, to streets for families use in order to decrease urban heat islands and reduce noise. The urban greening projects were installed mainly in private, residential, commercial, educational and governmental buildings. The main motivation for urban greening projects was environmental or aesthetic purposes within research aims. Parks and for general citizens are positive determinant factors for public urban greening due to their high visibility and general benefits to citizens. This study contributes to the literature by investigating the realities, evolution and prospects of public urban greening from an international point of view.

\section{Future research lines}

Despite the role of urban greening in resolving the lack of green space in urbanised areas and the environmental benefits and advantages of the buildings previously presented, there are still some economic, technical and social scopes of research for the wide integration of urban greening in cities. The future adoption of urban greening in many countries will depend on expertise. The development of urban greening requires more research into the load capacity of the existing roof structure, the overshadowing of the existing roof, the orientation as substrate materials and plant types, because some of them are unlikely to survive long periods of hot and dry weather without intensive irrigation. The assessment of the vegetation used in urban greening, and how vegetation choices and gardening practices interact to configure biodiversity in the city, have not yet been systematically investigated. The future adoption of urban greening in many countries will depend of economies of scale. More geographically diverse research is needed, including comparative studies of urban greening in different social and political contexts, before we can obtain a more accurate assessment of the characteristics, motivations, benefits and challenges for urban greening globally. It is necessary to know how social and political commitments surround the procurement of urban greening. The adoption of urban greening will require the investigation of users' commitment to ensuring the effectiveness of urban greening with a view of the social dimension.

\section{References}

Abass, K, Appiah, D.O. and Afriyie, K., 2019. Does green space matter? Public knowledge and attitude towards urban greenery in Ghana. Urban Forestry \& Urban Greening, 46, pp. 126462.

Alexandri, E. and Jones, P., 2008. Temperature decreases in an urban canyon due to green walls and green roofs in diverse climates. Building and Environment, 43, pp. 480-493. 
Akther, M., He, J., Chu, A., Huang, J. and van Duin, B., 2018. A Review of Green Roof Applications for Managing Urban Stormwater in Different Climatic Zones. Sustainability, 10, pp. 2864.

Barfod, K., Ejbye-Ernst, N., Mygind, L. and Bentsen, P., 2016. Increased provision of udeskole in Danish schools: An updated national population survey. Urban Forestry \& Urban Greening, 20, pp. 277-281.

Beilin, R. and Hunter, A., 2011. Co-constructing the sustainable city: how indicators help us 'grow' more than just food in community gardens. Local Environment, 16, pp. 523-538.

Berardi, U., GhaffarianHoseini, A.H. and GhaffarianHoseini, A., 2014. State-of-the-art analysis of the environmental benefits of green roofs. Applied Energy, 115, pp. 411-428.

Brenneisen, S., 2004. Green roofs: How nature returns to the city. Acta Horticulturae, 643, pp. 289-293.

Brown, F., Rickaby, P.A., Bruhns, H.R. and Steadman, P., 2000. Surveys of nondomestic buildings in four English towns. Environment and Planning B: Planning and Design, 27, pp. 11-24.

Buildingradar, 2019. Green roofs-more than just a trend? [online] Available at: $<$ https://buildingradar.com/construction-blog/green-roofs/> [Accessed 14 December 2019].

Carter, T. and Fowler, L., 2008. Establishing green roof infrastructure through environmental policy instruments. Environmental Management, 42(1), pp. 151-164.

Carter, T. and Keeler, A., 2008. Life-cycle cost-benefit analysis of extensive vegetated roof systems. Journal of Environmental Management, 87(3), pp. 350-363.

Castleton, H.F., Stovin, V., Beck, S.B.M. and Davison, J.B., 2010. Green roofs; building energy savings and the potential for retrofit. Energy and Buildings, 42, pp. 1582-1591.

Comassetto, B.H., Solalinde, Z.G.P., De Souza, J.V.R., Trevisan, M., Abdala, P.R.Z. and Rossi, C.A.V., 2013. Nostalgia, symbolic anticonsumption and well-being: urban agriculture. Revista de Administracao de Empresas, 53(4), pp. 364-375.

Comstock, N., Miriam Dickinson, L., Marshall J.A., Soobader, M.J., Turbin, M.S., Buchenau, M. and Litt, J.S., 2010. Neighbourhood attachment and its correlates: Exploring neighbourhood conditions, collective efficacy, and gardening. Journal of Environmental Psychology, 30, pp. 435-442.

CNN Technology, 2008. Green roofs cool cities, combat climate change, say Germans, [online] Available at: <http://edition.cnn.com/2008/TECH/science/06/26/ green.roofs/index.html> [Accessed 14 December 2019].

Deloitte, D.J. and Grant, G., 2009. Greater Manchester Green Roof Programme Guidance Document. Manchester City Council: Manchester, UK.

Dunnett, N., and Kingsbury, N., 2004. Planting Green Roofs and Living Walls. Timber Press: Portland Oregon.

Egerer, M., Ordóñez, C., Lin, B.B. and Kendal, D., 2019. Multicultural gardeners and park users benefit from and attach diverse values to urban nature spaces. Urban Forestry \& Urban Greening, 46, pp. 126445.

FAO, 2012. Growing greener cities in Africa. First status report on urban and peri-urban horticulture in Africa. Rome: Food and Agriculture Organization of the United Nations. 
FAO, 2019. Greener cities: Cities of despair- or opportunity? Rome: Food and Agriculture Organization of the United Nations.

Getter, K.L., Rowe D.B. and Cregg, B.M., 2009. Solar radiation intensity influences extensive green roof plant communities. Urban Forestry \& Urban Greening, 8(4), pp. 269-281.

Guitart, D., Pickering, C. and Byrne, J., 2012. Past results and future directions in urban community gardens research. Urban Forestry \& Greening, 11, pp. 364-373.

Heynen, N., Perkins, H.A. and Roy, P., 2006. The political ecology of uneven urban green space: the impact of political economy on race and ethnicity in producing environmental inequality in Milwaukee. Urban Affairs Review, 42, pp. 3-25.

Hiu, H., Clark, C., Zhouo, J. and Adriaens, P., 2010. Scaling of economic benefits from green roof implementation in Washington DC. Environmental Science Technology, 44, pp. 4302-4308.

Hong, W., Guo, R. and Tang, H., 2019. Potential assessment and implementation strategy for roof greening in highly urbanized areas: A case study in Shenzhen, China. Cities, 95, pp. 102468.

Kim, J.M., Hong, T.H. and Koo, C.W., 2012. Economic and Environmental Evaluation Model for Selecting the Optimum Design of Green Roof Systems in Elementary Schools. Environmental Science \& Technology, 46(15), pp. 8475-8483.

Köhler, M. and Poll, P.H., 2010. Long-term performance of selected old Berlin greenroofs in comparison to younger extensive greenroofs in Berlin. Ecological Engineering, 36(5), pp. 722-729.

Koprowska, K., Łaszkiewicza, E. and Kronenberga, J., 2020. Is urban sprawl linked to green space availability? Ecological Indicators, 108, pp. 105723.

Kurtz, H., 2001. Differentiating multiple meanings of garden and community. Urban Geography, 22(7), pp. 656-670.

Livingroofs, 2019. London 2019 Green Roof report. The UK's Leading Independent Green Roof Website, [online] Available at: <http://www.livingroofs.org/ livingpages/auditlondon.html> [Accessed 14 December 2019].

Loh, S., 2008. Living walls-way to green the built environment. BEDP Environment Design Guide, 1(26), pp. 1-7.

Lundholm, J., MacIvor, J.S., MacDougall, Z. and Ranalli, M., 2010. Plant Species and Functional Group Combinations Affect Green Roof Ecosystem Functions. PLoS One, 5(3), e9677.

Mickovski, S.B., Buss, K., McKenzie, B.M. and Sokmener, B., 2013. Laboratory study on the potential use of recycled inert construction waste material in the substrate mix for extensive green roofs. Ecology Engineering, 61, pp. 706-714.

Milligan, C., Gatrell, A. and Bingley, A., 2004. "Cultivating health": Therapeutic landscapes and older people in England. Social Science \& Medicine, 58, pp. 1781-1793.

Niachou, A., Papakonstantinou, K., Santamouris, M., Tsangrassoulis, A. and Mihalakakou, G., 2001. Analysis of the green roof thermal properties and investigation of its energy performance. Energy and Buildings, 33(7), pp. 719-729. 
Park, C.Y., Yoon, E.J., Lee, D.K. and Thorne, J.H., 2020. Integrating four radiant heat load mitigation strategies is an efficient intervention to improve human health in urban environments. Science of The Total Environment, 698, pp. 134259.

Popescu, D., Bienert, S., Schützenhofer, C. and Boazu, R., 2012. Impact of energy efficiency measures on the economic value of buildings. Applied Energy, 89, pp. 454-463.

Pudup, M.B., 2008. It takes a garden: Cultivating citizen-subjects in organized garden projects. Geoforum, 39(3), pp. 1228-1240.

Qin, X., Wu, X., Chiew, Y.M. and Li, Y., 2013. A green roof test bed for stormwater management and reduction of Urban Heat Island effect in Singapore. British Journal of Environment \& Climate Change, 2(4), pp. 410-420.

Schweitzer, O. and Erell, E., 2014. Evaluation of the energy performance and irrigation requirements of extensive green roofs in a water-scarce Mediterranean climate. Energy and Buildings, 68, pp. 25-32.

Steadman, P., Rickaby, P. and Brown, D., 2000. A classification of built forms. Environment and Planning B: Planning and Design, 27, pp. 73-91.

Sun, T., Grimmond, C.S.B. and Ni, G.H. 2016. How do green roofs mitigateurban thermal stress under heat waves? Journal of Geophysical Research: Atmospheres, 121, pp. 5320-5335.

UNFPA, 2007. State of the World Population 2007: unleashing the potential of urban growth. New York United Nations Population Fund.

Urbano-Lopez de Meneses, B., 2013. Urban Greening, an urbanization coping mechanism. Revista Chapingo serie ciencias forestales y del ambiente, 19, pp. 225-235.

Verbeke, W., 2015. Profiling consumers who are ready to adopt insects as a meat substitute in a Western society. Food Quality and Preference, 39, pp. 147-155.

Williams, N.S.G., Rayner, J.P. and Raynor, K.J., 2010. Green roofs for a wide brown land: opportunities and barriers for rooftop greening in Australia. Urban Forestry \& Urban Greening, 9(3), pp. 245-251.

Wilkinson, S. and Reed, R., 2009. Green roof retrofit potential in the central business district. Property Management, 27(5), pp. 284-301.

Wong, N.H., Tan, A.Y.K, Chen, Y., Sekar, K., Tan, P.Y., Chan, D., Chiang, K. and Wong, N.C., 2010. Thermal evaluation of vertical greenery systems for building walls. Building and Environment, 45(3), pp. 663-672.

Yamanaka, S., Ishiyama, N., Senzaki, M., Morimoto, J., Kitazawa, M., Fuke, N. and Nakamura, F., 2020. Role of flood-control basins as summer habitat for wetland species - A multiple-taxon approach. Ecological Engineering, 142, pp. 105617.

Yee Tse, M.M., 2010. Therapeutic effects of an indoor gardening programme for older people living in nursing homes. Journal of Clinical Nursing, 19, pp. 949-958.

Yin, H., Kong, F. Dronova, I., Middel, A. and James, P., 2019. Investigation of extensive green roof outdoor spatio-temporal thermal performance during summer in a subtropical monsoon climate. Science of the Total Environment, 696, pp. 133976.

Zhang, L., Deng, Z., Liang, L., Zhang, Y., Meng, Q., Wang, J. and Santamouris, M., 2019. Thermal behavior of a vertical green facade and its impact on the indoor and outdoor thermal environment. Energy and Buildings, 204, pp.109502. 